\title{
Statin use and peripheral sensory neuropathy: a pilot study
}

\author{
Brenton West ${ }^{1 *}$, Cylie Williams ${ }^{2,3}$, Elise Jilbert ${ }^{1}$, Alicia James ${ }^{1}$, Terry Haines ${ }^{2,3}$ \\ From Australasian Podiatry Council Conference 2013 \\ Sydney, Australia. 2-5 June 2013
}

\section{Background}

Peripheral sensory neuropathy is a neurological deficit resulting in decreased detection of sensation through the peripheral nervous system. Statins are a widely used medication and there has been some debate of association with their use and the presence of peripheral sensory neuropathy. This pilot study aimed to test the sensory perception of participants with long term statin use and compare these results to their peers who were not taking statins.

\section{Methods}

30 participants were recruited for this study and equally divided into a statin and non-statin group. Healthy participants were screened by their medical and medication history, Australian Type 2 Diabetes Risk assessment and random blood glucose level. An assessor who was blinded to the participant group conducted sensory assessments using the $10 \mathrm{~g}$ monofilament and neurothesiometer.

\section{Results}

There was no difference in monofilament testing results between the groups. The statin group was less sensate at the styloid process $(\mathrm{p}=0.031)$ and medial malleolus $(\mathrm{p}=0.003)$ than the control group. Results at the hallux were not statistically significant (0.183).

\section{Conclusion}

This result is suggestive of a potential association between long term statin use and the development of peripheral sensory neuropathy. As statins are a life saving medication, careful consideration should be applied to these results and further research be conducted to determine if these results are applicable to larger populations.

\footnotetext{
* Correspondence: brentonwest@phcn.vic.gov.au

${ }^{1}$ Peninsula Health Podiatry Department Frankston, VIC 3199, Australia

Full list of author information is available at the end of the article
}

Prescribers of statins should be aware and considerate of the potential decrease in sensory perception and monitor their foot health accordingly.

\section{Author details \\ ${ }^{1}$ Peninsula Health Podiatry Department Frankston, VIC 3199, Australia. ${ }^{2}$ Southern Health Allied Health Clinical Research Department, Cheltenham, VIC 3192, Australia. ${ }^{3}$ Monash University, Department of Physiotherapy, Frankston, VIC, 3199, Australia.}

Published: 31 May 2013
Submit your next manuscript to BioMed Central and take full advantage of:

- Convenient online submission

- Thorough peer review

- No space constraints or color figure charges

- Immediate publication on acceptance

- Inclusion in PubMed, CAS, Scopus and Google Scholar

- Research which is freely available for redistribution

Submit your manuscript at www.biomedcentral.com/submit
C Biomed Central 